\title{
ROLE OF CUSTOMS AND BORDER COOPERATION IN FIGHTING THE TERRORISM FINANCING AND FUNDING PROLIFERATION F. Tudor
}

\section{Florin Tudor}

The Faculty of Juridical, Social and Political Sciences/Administrative Sciences and Regional Studies Department

"Dunărea de Jos" University of Galaţi, Romania

*Correspondece: Florin Tudor, The Faculty of Juridical, Social and Political Sciences, Galaţi, Str. Domnească, nr. 111

Email: florin.tudor@ugal.ro

Abstract: In the context in which strategic objectives for of the customs union concerns, first of all, protecting the EU, international cooperation is in itself a strategy within the EU customs policy. This study seeks to identify concrete solutions that can restrict the financing acts of terrorism and crime in terms of economic and financial trade by reducing fraud and tax frontier. The involvement of international organizations specialized in trade facilitation and simplification of customs as well as development and implementation of international standards in security, can prioritize and identify timely the activities inconsistent with international agreements in combating the financing of terorsim and proliferation financing.

\section{Keywords: cooperation, funding, terrorism, crime, fraud}

\section{Introduction}

Through program documents, European Union, World Trade Organization and the World Customs Organization support international cooperation, but it is estimated that States Parties may intervene to prevent crime and adapting national legislation so that these do not host reprehensible deeds committed in their territories or outside their.

But the EU is more concerned with the supply chain for the safety of and combating fraud, identifying dual-use goods, intellectual property rights, the proper interpretation of rules of origin, but believes that the customs authorities and those competent for this phenomenon must have clear procedures and effective transmission and execution of requests for information or other ways of joint assistance ${ }^{1}$.

In the past decade there have been made substantial efforts to combat terrorist financing within the EU borders. There have been adopted, in a dynamic steady, legal instruments to enhance the capacity to identify funding sources, but they are not sufficient, efforts were directed further to new forms of cross-border cooperation.

The essence is that the border customs authorities must have at its disposal efficient mechanisms and channels for timely execution of all possible measures to prevent and counter any preparatory act for border crossing of goods likely to contribute to untaxed profits that can fund criminal acts.

\section{Strategy for development of the Customs Union}

Supervision and control of goods transiting the EU external borders is provided by the customs authority which grants released to free circulation or export. Customs Border is a leading provider of services to society through fiscal role that it has, but also for business, fulfilling a number of operational objectives.

\footnotetext{
${ }^{1}$ See Article 19 of the International Convention for the Suppression of Terrorism adopted in New York on 9 December 1999, ratified by Law 623 of November 19, 2002 published in the Official Gazette of Romania, Part I, no. 852 of 26 November 2002.
} 
In recent years, customs have increased competences to protect the safety and security of the EU, as guarantors of the numerous international agreements involving the trade flows of the EU and the Convention for the Suppression of Financing of terrorism and proliferation of weapons or the international acts to combat money laundering.

Several government agencies are based on the results of carrying out the formalities and control of goods, of application of common trade policy customs border, including in the areas such as agriculture, environment ${ }^{2}$, public health and consumer protection, drug precursors ${ }^{3}$, intellectual property rights ${ }^{4}$, etc. Through Community Customs Code and Customs tariffs is offered a solid legal basis for enforcement and compliance in the areas mentioned above.

The Customs Union has also competencies for achieving internal security ${ }^{5}$ and border security, in fact essential to the area of free movement. Goods entering the European area are subject to a risk analysis on the basis of common standards risk having priority to identify potentially dangerous goods. More recently, the system is based also on complementary tools of work, such as anticipated trade information of trade operations of economic operators.

Strategy for development of the Customs Union ${ }^{6}$ has held as priority objectives of the customs union: protecting EU and support EU competitiveness. These strategic goals can be achieved only by applying a uniform and by effective control and closer cooperation with other government authorities, with the business community and with international partners.

For the implementation of the mentioned is justified, however, better governance customs union which involves, first of all, better operational running of the 27 Customs administrations whereas these, although they have to apply a common but with national peculiarities, especially human and financial resources available in the various customs administrations, they must behave as if are one.

\section{Preventive measures to combat terrorist financing and proliferation financing}

External environment exerts a permanent pressure on the performance of the customs union. Trade flows are steadily growing in the last decade, business schemes are becoming increasingly complexand whith new logistics and competitive market pressures make increasingly more difficult to apply the EU common commercial policy.

Regarding internal securityand even foreign, customs authorities and other government agencies are facing in Europe, with significant legal reforms and whith increased pressure from unexpected tasks, the need for new competences backed by the economic crisis which put pressure on resources, makes it an vulnerable to subsist as long as the international supply chain risks have increased due to the globalization of crime and terrorist activities.

It is well known that there are conceptual differences regarding the management of customs risk and control measures at the EU customs administrations. For better protection of EU financial interests is required additional risk management measures and the approaches must target also the component regarding the cross-border cooperation with the nonUE states states, but who affirmed their international support to combat acts of terrorism and stop, in any way, the financing of terrorism and proliferation of weapons of mass destruction.

In another context, each Member State is obliged to publicly reaffirm and to criminalize terrorist financing under the Convention on financing terrorism, through criminal codes. Financing terrorist organizations and terrorist individuals must have a correspondent between crimes.

\footnotetext{
See Regulation (EC) no. 338/97 on the protection of species of wild fauna and flora by regulating trade therein. http://ec.europa.eu/enterprise/sectors/chemicals/documents/specific-chemicals/precursors/

4 Council Regulation (EC) No. 1383/2003 of 22 July 2003 concerning customs action against goods suspected of infringing certain intellectual property rights and the measures to be taken against goods found to have infringed such rights.

5 See, eg, Communication from the Commission to the European Parliament and the Council of 22 November 2010 - The EU Internal Security Strategy in Action: Five steps towards a more secure Europe [COM (2010) 673 final - Not published in the Official Journal].

6 COM (2008) 169 final.
} 


\section{F.Tudor}

Rules on penalties should be in accordance with the resolutions of the Security Council of the United Nations for preventing and combating terrorism and terrorist acts. Resolutions oblige states to block immediately the funds or any asset, so that, directly or indirectly, they are not for the benefit of anyone suspected of possible terrorist acts ${ }^{7}$.

Member States should ensure that financial institutions legislation does not conflict with the recommendations of the Financial Action Task Force (FATF) ${ }^{8}$.

Financial institutions should not invoke secrecy or confidentiality of the transaction and should take measures to identify the identity of customers when carrying out occasional transactions above the limit set (15.000 USD / EUR); there is suspicion of money laundering or terrorist financing; there are serious doubts about the veracity or adequacy of previously obtained customer identification data.

\section{Conclusions}

Regarding the international dimension of the Customs Union's priority is to secure the supply chain by developing international standards and trade facilitation amid the fight against fiscal fraud that can stop, and in this case, the financing of terrorism.

Member States must take decisive action to implement the Vienna Convention, 1988; United Nations International Convention for the Suppression of the Financing of Terrorism, 1999; Inter-American Convention against Terrorism, 2002 and Council of Europe Convention on Laundering, Search, Seizure and Confiscation of the crime and on the financing of terrorism in 2005 .

In terms of mutual legal assistance, are required new rules to intensify cross-border and international cooperation, including the creation of a system for case management.

It requires the initiation of another adequate legal framework for mutual legal assistance in customs matters / tax, a official mechanism for criminal investigation, civil and administrative, exchange of indictments, other mechanisms to strengthen cooperation in the field of investigations and judicial proceedings relating to the financing terrorism, terrorist acts and terrorist organizations.

\section{References:}

- International Convention for the Suppression of Terrorism adopted in New York on 9 December 1999, ratified by Law 623 of November 19, 2002 published in the Official Gazette of Romania, Part I, no. 852 of 26 November 2002;

- Regulation (EC) no. 338/97 on the protection of species of wild fauna and flora by regulating trade therein;

- Council Regulation (EC) No. 1383/2003 of 22 July 2003 concerning customs action against goods suspected of infringing certain intellectual property rights and the measures to be taken against goods found to have infringed such rights;

- Communication from the Commission to the European Parliament and the Council of 22 November 2010 - The EU Internal Security Strategy in Action: Five steps towards a more secure Europe [COM (2010) 673 final - Not published in the Official Journal];

- Communication from the Commision to the Council, the European Parliament and the European Economic and Social Committee COM(2008) 169 final;

- UN Charter of 26 June 1945 issued by the UN published in the Official Gazette from June 26, 1945.

\footnotetext{
7 For details, the UN Security Council, under Chapter VII of the UN Charter, including, in accordance with resolution 1267 (1999) and subsequent resolutions; or designated by that country under the resolution 1373 (2001).

8 The Financial Action Task Force (FATF) is an inter-governmental body established in 1989 by the Ministers of its Member jurisdictions. The objectives of the FATF are to set standards and promote effective implementation of legal, regulatory and operational measures for combating money laundering, terrorist financing and other related threats to the integrity of the international financial system.
} 